\title{
Distribution of the East China Sea continental shelf basins and depths of magnetic sources
}

\author{
Jing-Yi Lin ${ }^{1}$, Jean-Claude Sibuet ${ }^{1}$, and Shu-Kun $\mathrm{Hsu}^{2}$ \\ ${ }^{1}$ Ifremer, Centre de Brest, B.P. 70, 29280 Plouzané Cedex, France \\ ${ }^{2}$ Institute of Geophysics, National Central University, Chung-Li 32054, Taiwan
}

(Received March 2, 2005; Revised June 30, 2005; Accepted July 18, 2005)

\begin{abstract}
The acoustic basement map of the East China Sea, established by the Shanghai Offshore Petroleum Bureau with all available industry seismic data, shows the existence of a 30-km-wide, 10-km-deep basin, that we named the Ho Basin. The Ho Basin belongs to a series of elongated deep basins extending over $600 \mathrm{~km}$ east of the Taiwan-Sinzi Ridge and flanked to the East by a ridge named the Longwan Ridge in its northern part. This new system of basin and ridge was probably formed during middle Miocene, sometimes in between rifting episodes occurring in the Taipei Basin and Okinawa Trough. It complements the already defined system of five belts of backarc basins and associated arc volcanic ridges in the East China Sea, which are progressively younger from the Mainland China shoreline (late Cretaceous/early Tertiary) to the Okinawa Trough (Present). In order to determine the crustal thickness beneath the East China Sea continental shelf, we used a power spectrum method to calculate the depth of the top $(Z t)$ and the centroid $(Z o)$ of the magnetic basement by fitting a straight line through the high- and low-wave number portions of the power spectrum, respectively. Then, the depth of the base $(Z b)$ is estimated from $Z t$ and $Z o$. After optimizing the size of the data squares, we demonstrate that, except for basins more than $10 \mathrm{~km}$ deep, $Z t$ corresponds to the basement depths and $Z b$, the depth of the Curie point, to the Moho depth. As wide-angle reflection and refraction data are scarce in the East China Sea, this method provides a way to characterize the crustal thickness of the East China Sea and to compute the theoretical heat flow values.
\end{abstract}

Key words: East China Sea, backarc basins, spectral analysis, depth of magnetic sources.

\section{Introduction}

The depth of magnetic sources can be estimated by spectral analysis. If the basement rocks are magnetized, the top of the calculated magnetic sources $(\mathrm{Zt})$ might correspond to the top of geological basement, and the base of magnetic sources $(Z b)$ is assumed to be at the depth of the Curie point. At temperatures greater than the Curie point, rocks are paramagnetic. Compared to shallow sources, deep magnetic sources produce low-amplitude and long-wavelength magnetic anomalies. Tanaka et al. (1999) have developed a method, similar to the one of Spector and Grant (1970), which allows to calculate depths of the top $(Z t)$ and the centroid $(Z o)$ of a magnetic source by fitting a straight line through the high- and low-wave number portions of the power spectrum, respectively. The base of the magnetic source $(Z b)$ is estimated from $Z o$ and $Z t$.

Previous analysis of the structure and timing of the East China Sea continental shelf basins shows that they are located within five belts parallel to the Mainland Chinese shoreline (Sibuet and Hsu, 1997; Sibuet et al., 2004) (Fig. 1). Since late Cretaceous, these belts of basins become younger oceanward and ridges with volcanic products are present in between. Sibuet and Hsu (1997) have interpreted these belts of basins and associated ridges as relict backarc

Copyright (c) The Society of Geomagnetism and Earth, Planetary and Space Sciences (SGEPSS); The Seismological Society of Japan; The Volcanological Society of Japan; The Geodetic Society of Japan; The Japanese Society for Planetary Sciences; TERRAPUB. basins and remnants portions of volcanic arcs of the Ryukyu subduction system, respectively. In this paper, we provide a new detailed acoustic basement depth map established from oil industry seismic data (Shanghai Offshore Petroleum Bureau, personal communication, 1996), which shows that six belts of backarc basins and associated remnant arcs exist on the East China Sea continental shelf (Figs. 2(b) and (d)). The crust of the continental shelf is consequently not a typical continental crust but might include a large amount of arc volcanic products characterized by a significant magnetization. In the second part of this paper, we will use a spectral analysis method developed by Tanaka et al. (1999) and applied to available magnetic data to calculate the 3-D shape of the top of the magnetic basement $(\mathrm{Zt})$ and the base $(Z b)$ of the magnetic layer in the East China Sea. We will compare the $Z t$ distribution with the basement depth distribution established from industry seismic data and will use the $Z b$ distribution to discuss the thermal structure of this region.

\section{Geological Setting}

The Tertiary basins of the East China Sea are roughly oriented NE-SW (Letouzey et al., 1988), i.e. parallel to the East China shoreline and margin (Figs. 1 and 2(a)). The tectonic history of these basins shows that rifting occurred between late Cretaceous/early Paleocene and middle Miocene (65-15 Ma), and since middle Miocene for the active Okinawa Trough (OT), a backarc basin which is still in the rift- 


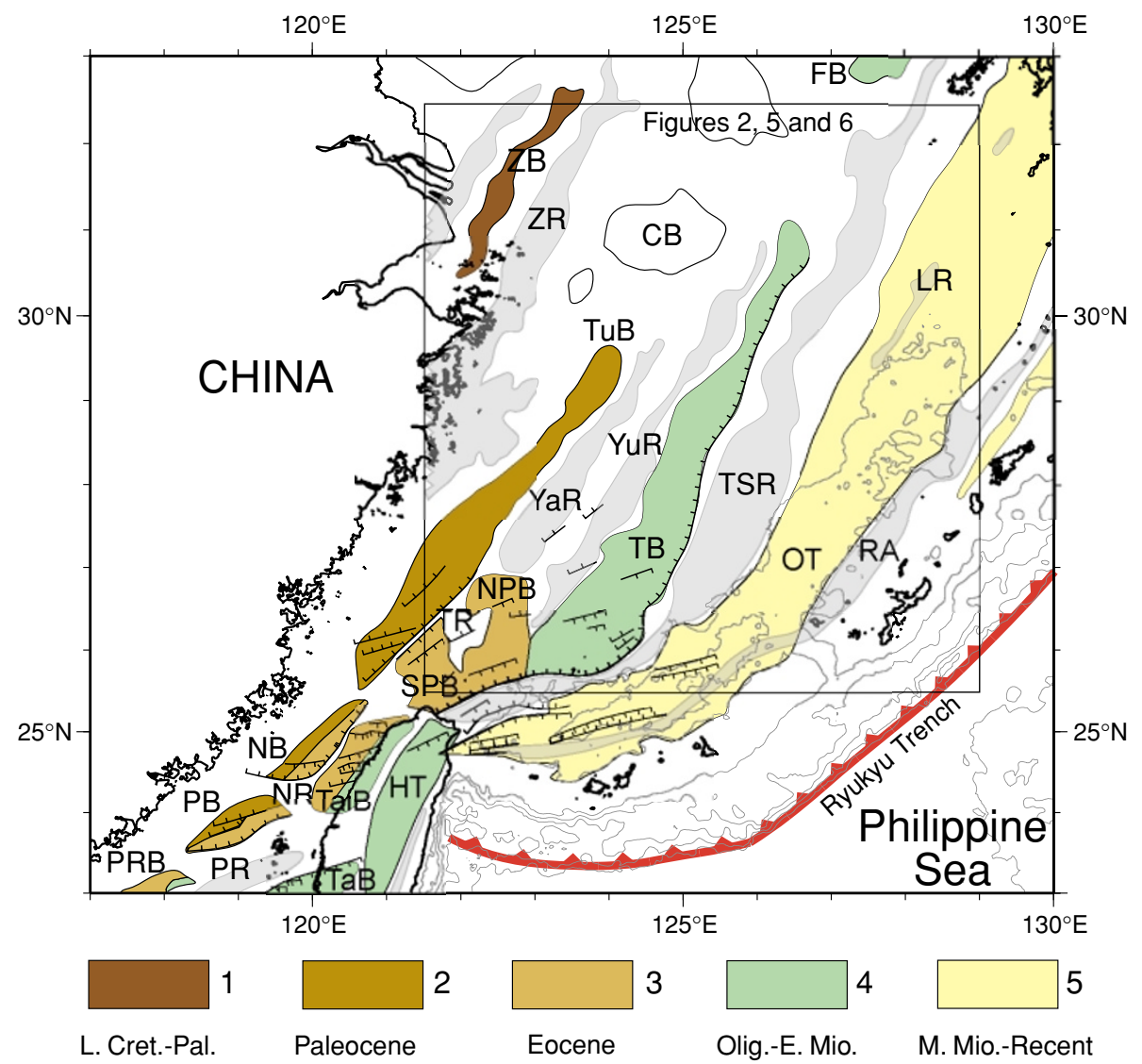

Fig. 1. East China Sea continental shelf basins with their main normal faults (Hsu et al., 2001; Sibuet et al., 2004). Colors denote the period during which the main rifting phases occurred in these basins: 1) Late Cretaceous/early Paleogene; 2) Paleocene; 3) Eocene; 4) Oligocene-early Miocene; 5) Late Miocene to Present. In gray, ridges locate between basins. CB, Changjiang Basin; FB, Fujiang Basin; HT, Hsüehshan Trough; LR, Longwan Ridge; NB, Nanjihtao Basin; NPB, North Pengchiahsu Basin; NR, Nanjihtao Ridge; OT, Okinawa Trough; PB, Penghu Basin; PR, Penghu Ridge; PRB, Pearl River Basins; RA, Ryukyu Arc; SPB, South Pengchiahsu Basin; TB, Taipei Basin; TaiB, Taishi Basin; TaB, Tainan Basin; TR, Tungyintao Ridge; TSR, Taiwan-Sinzi Ridge; TuB, Tungyintao and Tahchentao Basins; YaR, Yandang Ridge; YuR, Yushan Ridge; ZB, Zhemin Basin; ZR, Zhemin Ridge.

ing stage (Sibuet et al., 1987). Though some uncertainties exist concerning the exact beginning and end of the main rifting phases, largely because the shutdown tensional rifting activity could be interpreted as part of the postrift thermal subsidence phases or because minor extensional tectonic phases could complicate the interpretation, a careful determination of the timing of rifting of the East China Sea basins has been previously established by Sibuet and Hsu (1997). Five belts of basins corresponding to five different rifting phases were identified in the East China Sea (Sibuet and Hsu, 1997; Sibuet et al., 2004) (Fig. 1): (1) the oldest belt of basins formed during the late Cetaceous/early Paleocene and consists of the Zhemin Basin; (2) the second belt formed during Paleogene and consists of the Tungyintao and Tahchentao Basins; (3) Extension decreased and ceased in the previous basins but started during early Eocene in the South and North Pengchiahsu Basins, which formed the third belt; (4) The fourth belt formed during Oligoceneearly middle Miocene and consists of the Taipei Basin, a basin located southeast of those previously formed; (5) rifting ceased in all basins and started in the Okinawa Trough (last belt) during the late middle Miocene (12 Ma) or perhaps later during the late Miocene (6 Ma) (Sibuet et al., 1987).
The oceanward decreasing ages of rifting episodes and the orientation of all continental shelf basins of the East China Sea parallel to the margin are consistent with the idea that these shelf basins were formed as backarc basins related to the Ryukyu subduction zone, and were active at least from late Cretaceous to middle Miocene (Sibuet and Hsu, 1997; Sibuet et al., 2004). Such an interpretation had been already proposed at a regional scale for the northern Taiwan Basins by Huang et al. (1992) and Chi (1996).

The Taiwan-Sinzi Ridge (Fig. 1), located between the Taipei Basin and the Okinawa Trough, is associated with a large positive free-air anomaly (Sibuet et al., 2004). It is composed of paleo-highs made of deformed metamorphic rocks of Cretaceous age or older, intruded by Miocene volcanic rocks which crop out in the Sinkoku, Danjyo and northwest Kyushu islands. Strong positive magnetic anomalies (GSJ and CCOP, 1994) over the Taiwan-Sinzi Ridge (Fig. 2(c)) suggest the existence of a continuous remnant volcanic arc. Other ridges have been identified between the East China shelf basins and might be also considered as remnants of volcanic island arcs (Fig. 2). For example, between the Tungyintao and Pengchiahsu Basins, arc volcanic rocks of probable Paleogene age exist on the Tungyintao Ridge and are associated with significant pos- 

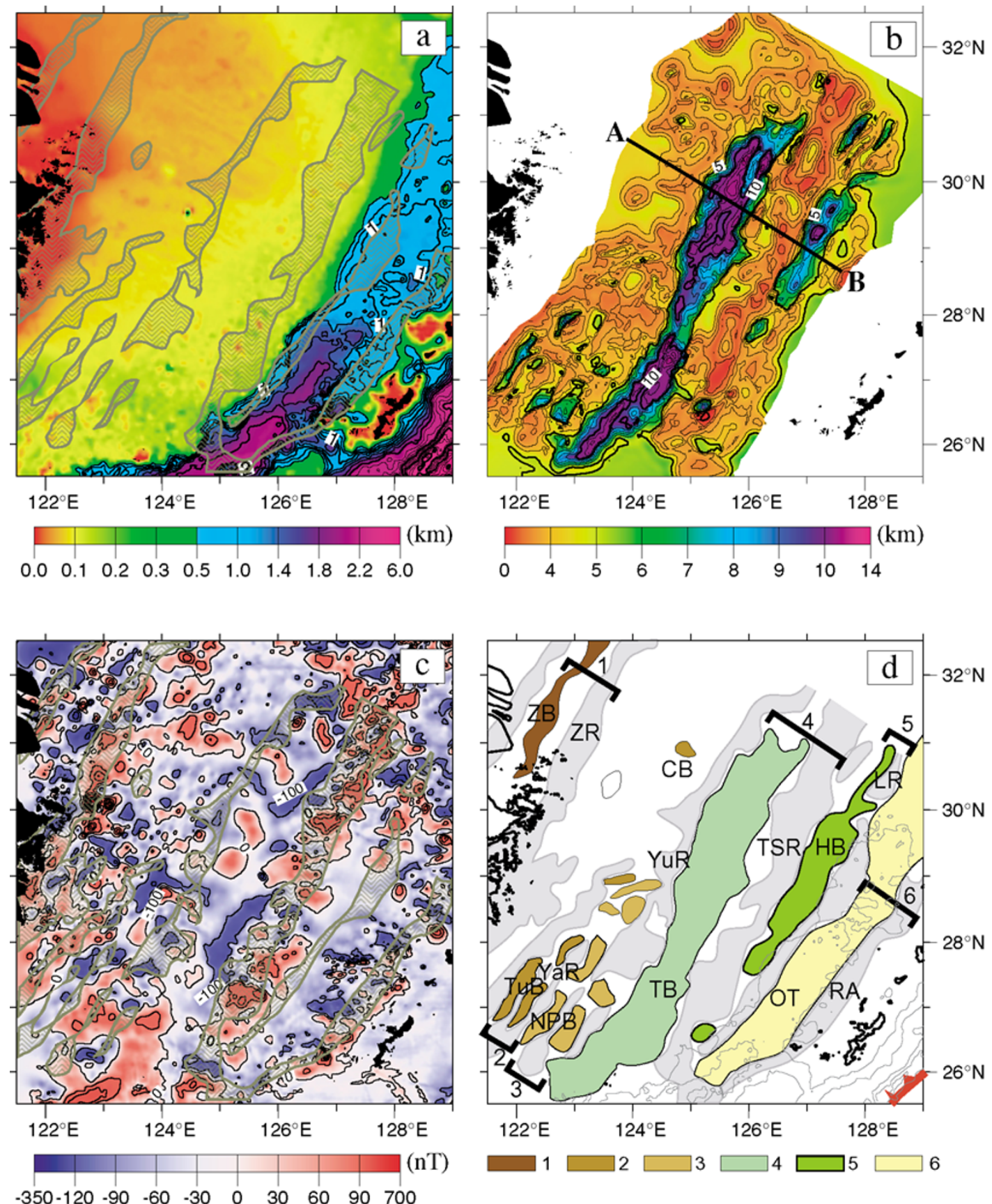

Fig. 2. Bathymetry, basement depth and magnetic anomaly maps of the portion of East China Sea located in Fig. 1. Names of features as in Fig. 1. a) Bathymetry extracted from Sandwell and Smith (1994). In gray, location of ridges extracted from Fig. 2(d). b) Basement depths were digitized and gridded every minute $(\sim 2 \mathrm{~km})$ from the basement depth map established by the Shanghai Offshore Petroleum Bureau (personal communication, 1996) with all available oil industry seismic data in 1996. Contours every km. c) Total-field magnetic anomalies extracted from the one-minute grid of the Magnetic Anomaly Map of East Asia (GSJ and CCOP, 1994). Contours every $50 \mathrm{nT}$. In gray, ridges from Fig. 2(d). d) Geographical extent of East China Sea continental shelf basins defined from the basement depth and magnetic anomaly maps of Figs. 2(b) and (c). Colors denote the time during which the six main rifting phases occurred in these basins: 1) Late Cretaceous/Paleocene; 2) Paleocene; 3) Eocene; 4) Oligocene-Early Miocene; 5) Middle Miocene; 6) Late Miocene to Present. Ridges between basins are marked in gray. Numbers 1 to 6 correspond to each pair of backarc basin and remnant volcanic arc located on the eastern side of the basin, from the older to the recent one. HB, Ho Basin.

itive magnetic anomalies. The magnetization map of the East China Sea (Hsu et al., 2001) also shows the location of several ridges in that area as the Nanjihtao Ridge, located between the Nanjihtao and Taishi Basins, though no relative positive gravity anomaly is associated with.

We have interpreted these ridges, generally associated with positive or relatively positive gravity anomalies and often-positive magnetic anomalies as remnant volcanic arcs whose formation is linked to the Ryukyu subduction zone (Sibuet et al., 2004). As for the shelf basins, five belts of remnant arcs were identified on the East China Sea continental shelf: 1) the oldest one mostly formed during late Cretaceous/Paleogene and consists of the Zhemin Ridge; 2) the second one mostly formed during Paleo- 
gene and consists of the Yandang and Tungyintao Ridges; 3 ) the third belt formed later during Eocene and includes the Yushan Ridge; 4) the fourth belt formed mostly during Oligocene and early Miocene and consists of the TaiwanSinzi Ridge; 5) the last belt corresponds to the Ryukyu Arc and formed since middle Miocene (Sibuet et al., 1995, 1998, 2004) (Fig. 1). Thus, we suggested that the belts of backarc basins and associated volcanic arcs were formed within the Ryukyu subduction system during five different periods: late Cretaceous/Paleocene, Paleocene, Eocene, Oligocene/early Miocene, and since middle Miocene. As soon as a backarc basin became too wide and fed too obliquely from the underlying slab, extension jumped from the axis of the backarc basin to the axis of the volcanic arc considered as a weak zone. Then, a new backarc basin started to open, leaving inactive on the continental side both the former backarc basin and a portion of the former arc (Sibuet and Hsu, 1997).

\section{Origin of Data and New Distribution of Backarc Basins and Ridges}

In the East China Sea, the data coverage of magnetic and seismic profiles is dense enough to produce grids with a 2$\mathrm{km}$ spacing. The total-field magnetic anomalies used in this study were extracted from the Magnetic Anomaly Map of East Asia (1994) (Fig. 2(c)). Both the magnetic anomaly map and the magnetization map, obtained by inverting the magnetic data (Hsu et al., 2001) in the sense of least-square error (Menke, 1984), show that positive magnetic anomalies and associated positive magnetization underlined the large Taiwan-Sinzi and Zhemin Ridges, but also, at a lesser degree, the present-day Ryukyu arc, the Yushan and the Yandang Ridges. Negative magnetic anomalies and associated negative magnetization anomalies underlined the Okinawa Trough, the Taipei Basin, the Tungyintao and Tahchentao Basins, but also small basins located between ridges of reduced geographical extent.

Basement depths were digitized and gridded from the basement depth contoured map established by the Shanghai Offshore Petroleum Bureau (personal communication, 1996) with all available industry seismic data in 1996 (Fig. 2(b)). This new document provides a considerable improvement of the East China Sea system of basins and ridges. The Taipei Basin is the largest and deepest basin. It extends northeast of Taiwan over $700 \mathrm{~km}$ from $25.7^{\circ} \mathrm{N}$ to $31^{\circ} \mathrm{N}$ latitude, is about $70 \mathrm{~km}$ wide and more than $10 \mathrm{~km}$ deep. On its eastern side, it is flanked by the Taiwan-Sinzi Ridge. On the eastern edge of the East China Sea and upper slope of the Okinawa Trough, lies a series of narrow basins aligned over $600 \mathrm{~km}$, from $26.3^{\circ} \mathrm{N}$ to $31^{\circ} \mathrm{N}$ latitude. They are parallel to the Taiwan-Sinzi Ridge and Taipei Basin. The northern basin was previously unknown. We named this basin the Ho Basin in memory of C.S. Ho, the famous pioneer of the Taiwan geology (Ho, 1984). As basins are older in the westward direction (Sibuet and Hsu, 1997), the Ho Basin is older than the Okinawa Trough and was probably formed during middle Miocene (sometimes between the ages of Taipei Basin and Okinawa Trough rifting episodes established by Sibuet and Hsu (1997)). This series of basins is flanked on its eastern side by a ridge named the Longwan
Ridge in the north (positive magnetic anomalies and positive magnetization values). To the south, the highest portion of the ridge is about $4 \mathrm{~km}$ deep and there are no significant magnetic anomalies associated with. Thus, both magnetic anomaly and basement depth maps show the existence of an additional belt of backarc basins and ridges.

Based on the interpretation of the magnetic anomaly (Fig. 2(c)), magnetization (Hsu et al., 2001) and basement (Fig. 2(b)) maps, and on the tectonic framework established by Sun (1981) and Liu (1992), we provide a new compilation of the distribution of the basins and basement ridges (Fig. 2(d)). The Okinawa Trough extends from Japan to Taiwan. The Taipei and the series of aligned basins, which includes the Ho Basin, are 700 and $600 \mathrm{~km}$ long, respectively. Except for the Zhemin Basin, all the other basins of the East China Sea do not exceed $150 \mathrm{~km}$ in length. These basins are about $5 \mathrm{~km}$ deep, compared with the Taipei and Ho basins, which are more than $10 \mathrm{~km}$ deep. In this new compilation, we recognize now six belts of backarc basins and associated arc volcanic ridges in the East China Sea (Fig. 2(d)). These belts are progressively younger from the Mainland China shoreline (Late Cretaceous/Early Tertiary) to the Okinawa Trough (middle Miocene to Present). Located on the westernmost part of the East China Sea, the oldest recognized basin and ridge system is the Zhemin Basin and the Zhemin Ridge. However, a large difference in size and depth exists between the three eastern and the three western belts of basins. This difference might be due to the late Eocene/early Oligocene change in the Ryukyu subduction parameters. For example, the steepness of the slab may have been different or a slab detachment may have occurred at that time. This last hypothesis is suggested by the 500-km-deep Ryukyu slab, which exhibits a discontinuity (e.g. Lallemand et al., 2001) corresponding to the location where the slab has been either overturned or detached. This change in the basin style might be also related to the major Philippine Sea kinematic change at 30-33 m.y. (Deschamps et al., 2002).

The interpretation of the magnetization and magnetic anomaly trends in the East China Sea only allows a qualitative interpretation concerning the location of sedimentary basins and basement ridges. However, the spectral analysis method, which could be used for wavelengths larger than 4 $\mathrm{km}$ (function of the 2-km magnetic grid spacing), will provide quantitative constraints on depths of the top and base of the magnetic sources.

\section{Methodology and Data Processing}

The method used to examine the statistical properties of magnetic data was developed by Tanaka et al. (1999). In order to estimate the depth and the vertical extent of magnetic bodies, several conditions must be fulfilled: 1) the horizontal dimension of a magnetic source must be much larger than the depth to its top, 2) the magnetization must be completely random and uncorrelated, and 3) the radial averages of magnetization and geomagnetic field direction must be constant. In such conditions, the radial average power spectra of the magnetic anomaly $(\Phi)$ could be simplified as:

$$
\Phi(|k|)=A e^{-2|k| Z t}\left(1-e^{-|k|(Z b-Z t)}\right)^{2}
$$



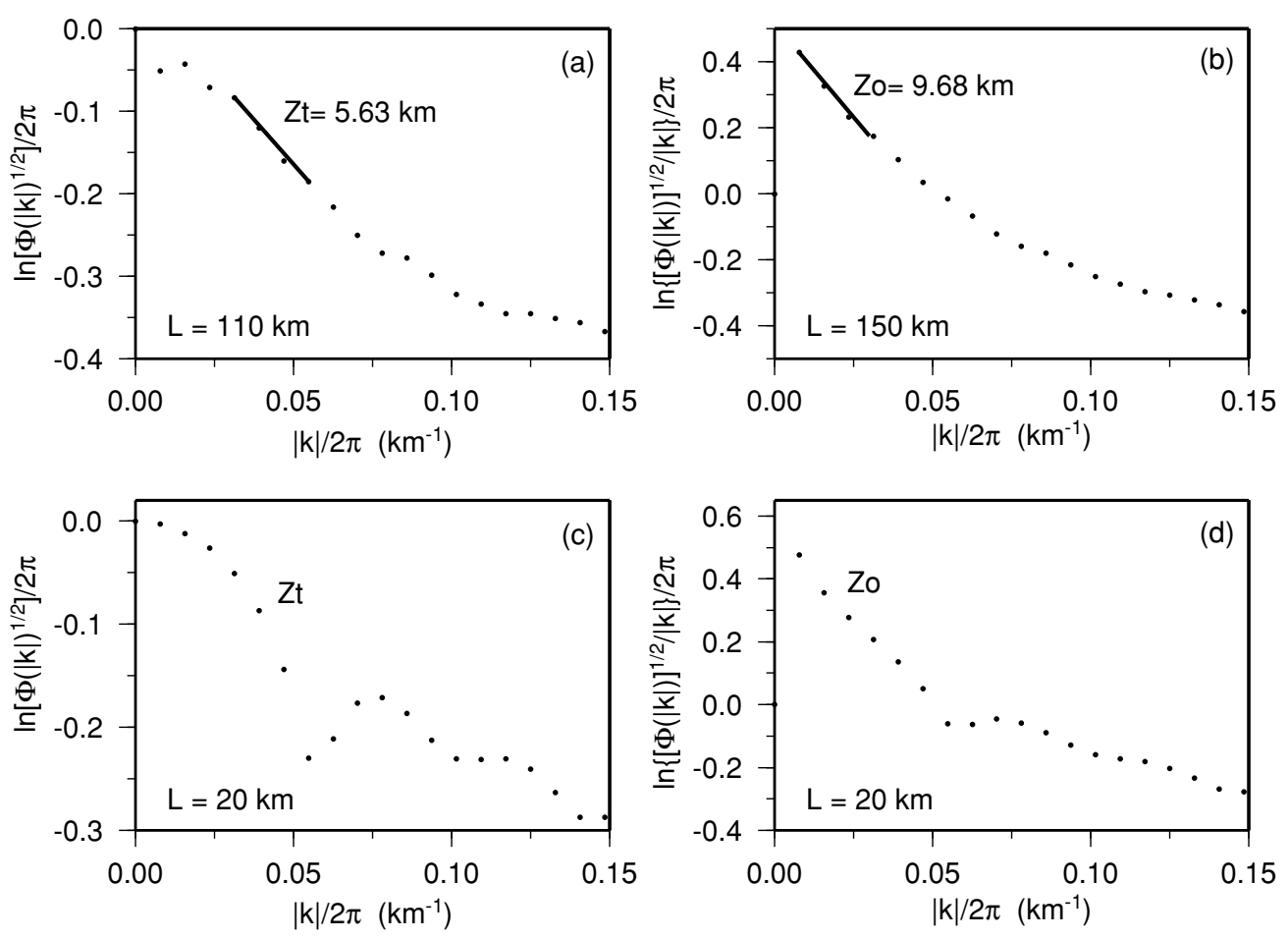

Fig. 3. Examples of power spectra defined from magnetic anomaly data to estimate $Z t$ and $Z o$ at $31.3^{\circ} \mathrm{N} ; 123.6^{\circ} \mathrm{E}$. Dots correspond to values of power spectrum. a) The top of the magnetic basement $Z t=5.63 \mathrm{~km}$ is obtained by fitting a straight line trough the high-wave number portion of data. $L=110 \mathrm{~km}$ is used in this case. b) The depth of the centroid $Z o=9.68 \mathrm{~km}$ is obtained by fitting a straight line through the low-wave number portion of data. $L=150 \mathrm{~km}$ is used in this case. c) and d) If $L$ is not large enough ( $L=20 \mathrm{~km}$ in this example), the logarithm of the power spectrum does not present any relationship with the wave number.

where $k$ is the wave number and $A$ is a constant.

(1)

When wavelengths are less than about twice the thickness of the magnetic source, Eq. (1) get close to:

$\ln \left[\Phi(|k|)^{1 / 2}\right]=\ln B-|k| Z t$ where $B$ is a constant.

At long wavelengths, Eq. (1) could be simplified as:

$\ln \left\{\left[\Phi(|k|)^{1 / 2}\right] /|k|\right\}=\ln C-|k| Z o$ where $C$ is a constant.

$Z t$ and $Z o$ represent a linear relation with the logarithm of the power spectrum. Therefore, the top and the centroid depth can be estimated by finding the slope in the high- and low-wave number parts of the radially averaged spectrum of $\ln \left[\Phi(|k|)^{1 / 2}\right]$ and $\ln \left\{\left[\Phi(|k|)^{1 / 2}\right] /|k|\right\}$, respectively. Then, the basal depth of the magnetic source is

$$
Z b=2 \times Z o-Z t
$$

As mentioned previously, several conditions should be assumed to simplify these equations. Furthermore, GarciaAbdeslem and Ness (1994) proposed that the shape of spectrum curve is independent of the inclination and declination of the local geomagnetic field and of the magnetization. Therefore, the spectrum slope would not be changed even if the distribution of magnetization is not random in the studied area.

The data are analyzed on a regular grid of points with 0.2 degree spacing. The magnetic anomalies used to determine the depth estimate are taken from a data square around each point of the grid. The Curie point depths $(Z b)$ are only calculated for wavelengths larger than $10 \mathrm{~km}$ (Stampolidis and Tsokas, 2002; Tanaka et al., 1999). Examples of power spectra of magnetic anomaly data are shown in Fig. 3, where $Z t$ and $Z o$ are obtained by computing power spectrum slopes for limited portions of high- and low-wave numbers (Figs. 3(a) and (b)).

\section{Depths of the Top of Magnetic Sources $(\mathrm{Zt})$}

For reasonable magnetic depth estimates, Okubo et al. (1985) suggested a ratio of 12 or 13 between the size L of the data square around the point of computation and the depth of the centroid. Shuey et al. (1977) demonstrated that the depth information from the power spectrum can only reach a depth of $L / 2 \pi$. To calculate $Z o$, Tanaka et al. (1999) divided their area of study into several sub-regions of $2 \times 2$ degrees in size. Figures 3(c) and (d) show the power spectra for $L=20 \mathrm{~km}$. For limited data coverage, logarithms of power spectra are not linear. Due to the lateral extension of magnetic sources or to boundary effects, the computed power spectrum contributions caused by the topography of magnetic sources might be smaller than the real one. Thus, if the size of data squares is too small, the method used here would not be suitable for the determination of $Z t$ and $Z o$. In order to optimize the size $L$ of data squares, we calculate linear regression lines between observed seismic basement depths and magnetic basement depths $Z t$ calculated for different values of $L$ (Fig. 4). Although depths of the top of magnetic source $(Z t)$ do not match exactly seismic basement depths, the linear slope of seismic basement depth and $Z t$ should be closed to 1 . In fact, linear slopes of 


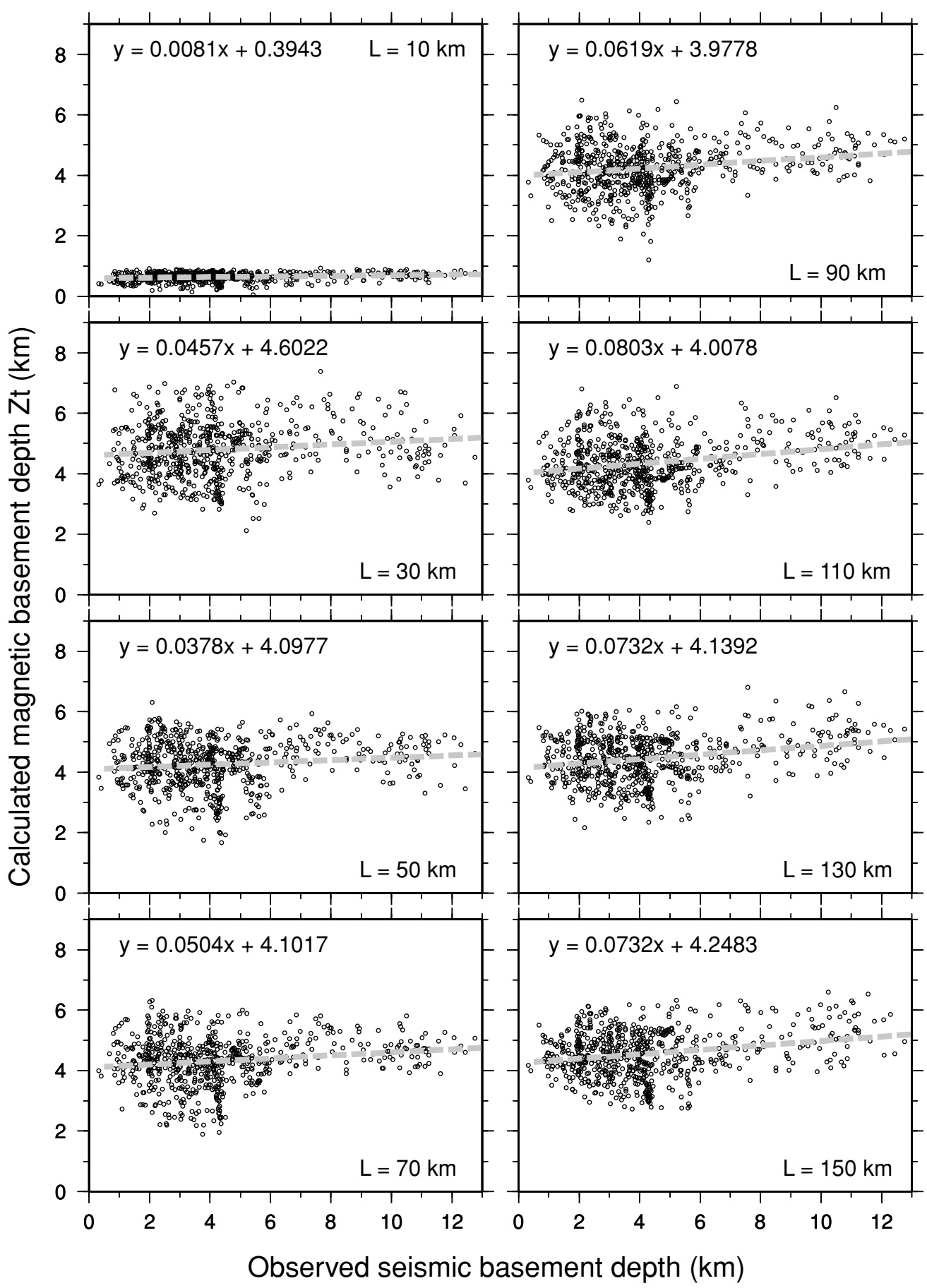

Fig. 4. Correlations between seismic basement depths of Fig. 2(b) and calculated depths of the top of magnetic sources ( $Z t$ ) for different size $L$ of the data squares. Dashed-gray lines are the linear regression lines.

all the regression lines are smaller than 1 .

We will use $L=110 \mathrm{~km}$ in the East China Sea because the linear slope is the largest. If $Z t$ values largely differ from a region to another one, a suitable size of data squares might be adopted. However, the intercepts of all the regression lines are close to $4 \mathrm{~km}$ (Fig. 4) except for $L=10 \mathrm{~km}$, suggesting that the depths of the top of magnetic sources would be about $4 \mathrm{~km}$ deeper than the seismic basement depths for areas where a shallow basement has been identified. Whatever is the size of the data squares, we could not find $Z t$ values reaching the deepest basement depths of the Taipei and Ho Basins (Fig. 5(d)) nor the high- est peak of the Taiwan-Sinzi Ridge. However, $Z t$ values seem to follow the other minor basement ridge undulations. These discrepancies might be due to the smoothing effect of the power spectrum estimation. Another explanation might be linked to the nature of the sediments that infill the shelf basins. Vander Zouwen (1985) and Hilde et al. (1984) demonstrated that sediments were transported by Mainland China rivers, deposited in basins close to the shoreline and then in younger shelf basins located eastward, bypassing the already infilled basins. If some of these sediments are the products of erosion of land volcanic features and/or remnant continental shelf arc ridges, the preferential orientation 

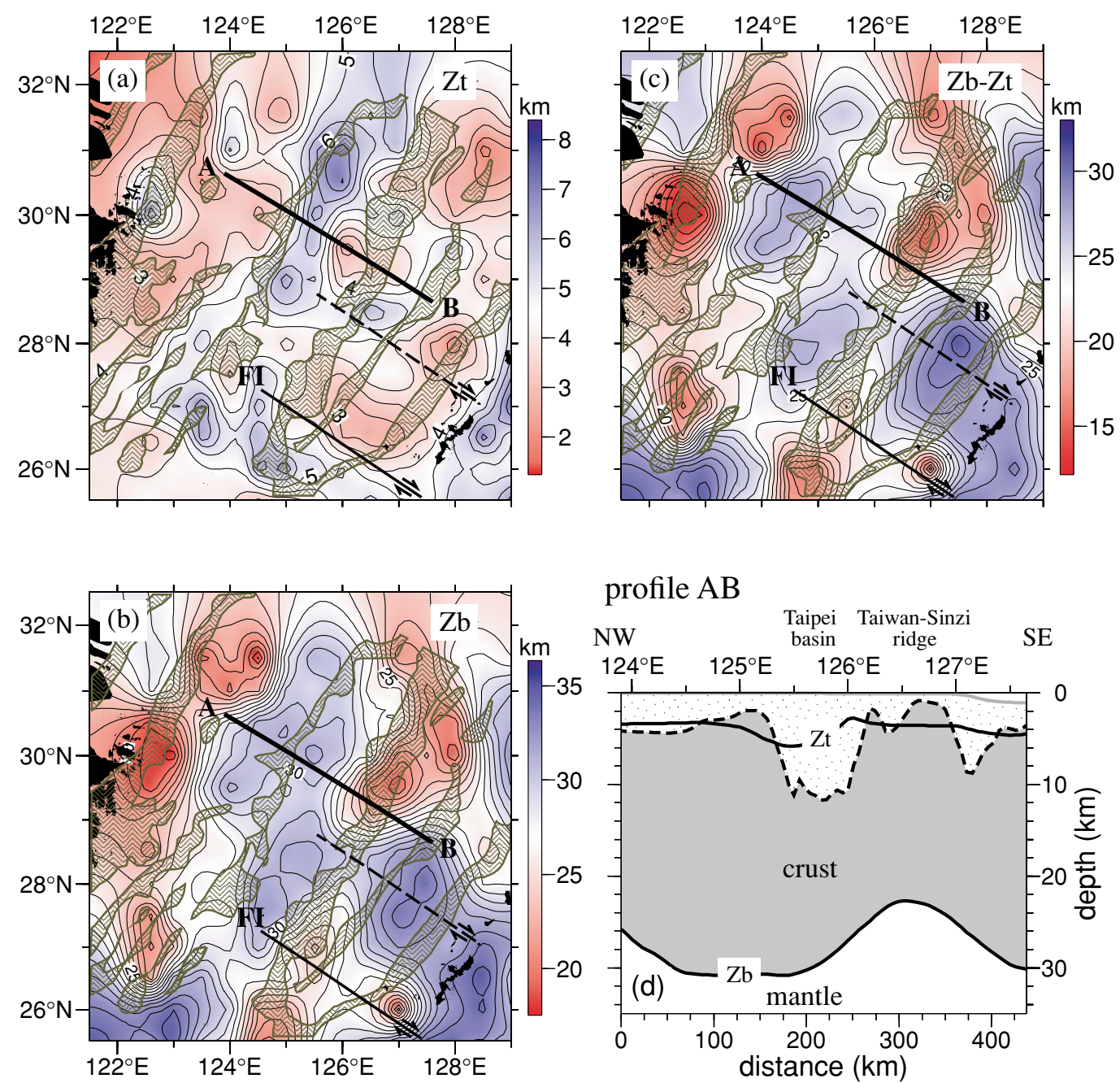

Fig. 5. (a) Depths of the top of magnetic sources $(Z t)$ for $L=110 \mathrm{~km}$. In gray, ridges from Fig. 2(d). (b) Depths of the base of magnetic sources ( $Z b$ ) for $L=150 \mathrm{~km}$; (c) Thickness of crust $(Z b-Z t)$. The thick black line is the location of profile AB. The black dashed line might be a possible right-lateral strike-slip fault (Hsu et al., 1996; Kong et al., 2000). (d) Comparison of $Z t$ values with seismic basement depths (dashed line) and $Z b$ along profile $\mathrm{AB}$.

of magnetic grains in the magnetic field of that epoch might provide some contribution to the observed magnetic field, explaining why $Z t$ values are not reflecting the topography of deep basins.

For $Z t$ values with $L=110 \mathrm{~km}$, we observed almost the same pattern of $Z t$ distribution and the same range of computed depths, roughly similar to the basement depths of Fig. 2(b), except for the shape and depth of deep basins, which do not fit the real data. In Fig. 5(a), the TaiwanSinzi Ridge and the Ryukyu Arc are cut by NW-SE trending features, which might correspond to right-lateral strike-slip faults as suggested by Hsu et al. (1996) and Kong et al. (2000) (Figs. 5(a) to (c)). For example, we have identified in Fig. 5(a) the FI feature, which separates the NW-SE trending shallow and deeper $Z t$ areas. This feature is known as a major feature separating the southern from the central Taiwan-Sinzi Ridge (Kong et al., 2000; Wageman et al., 1970).

\section{Depths of the Base of Magnetic Sources $(Z b)$}

When the size $L$ of data squares is larger than $110 \mathrm{~km}$, $Z b$ estimates deduced from $Z t$ and $Z o$ are more stable.
Therefore, the larger is the size $L$, the better are the results of $Z b$ estimates. For $L=150 \mathrm{~km}, Z b$ varies from 17 $\mathrm{km}$ to $33 \mathrm{~km}$ beneath the Okinawa Trough and the East China Sea (Fig. 5(b)). These values correspond to depths of the Curie point. As the Moho depths calculated from Bouguer anomaly data in this region (Jin et al., 1983; Sibuet et al., 1987) are close to $Z b$ values, we confirm that the Curie point depth is at or close to the Moho depth. The shallowest $Z b$ depth values $(17 \mathrm{~km})$ obtained for $L=150$ $\mathrm{km}$ present a NE-SW trending feature east of Taiwan-Sinzi Ridge (Fig. 5(b)). In the vicinity of $28^{\circ} \mathrm{N}$ latitude, the Taiwan-Sinzi Ridge is separated into two parts by a deep $Z b$ zone. As the southern limit of this deep $Z b$ zone follows the directions of the NW-SE trends already identified by Hsu et al. (1996) and Kong et al. (2000), this deep Z $Z$ zone might be a major boundary in the Okinawa Trough. We suggest that the presence of this deep $Z b$ zone is related to the collision of the Daito Ridge with the Ryukyu Arc and forearc and the subsequent subduction of the Daito Ridge as already proposed by Sibuet et al. (1998).

We have defined the thicknesses of the magnetic crust $(Z b-Z t)$ (Fig. 5(c)) from $Z t$ values obtained with $L=110$ 


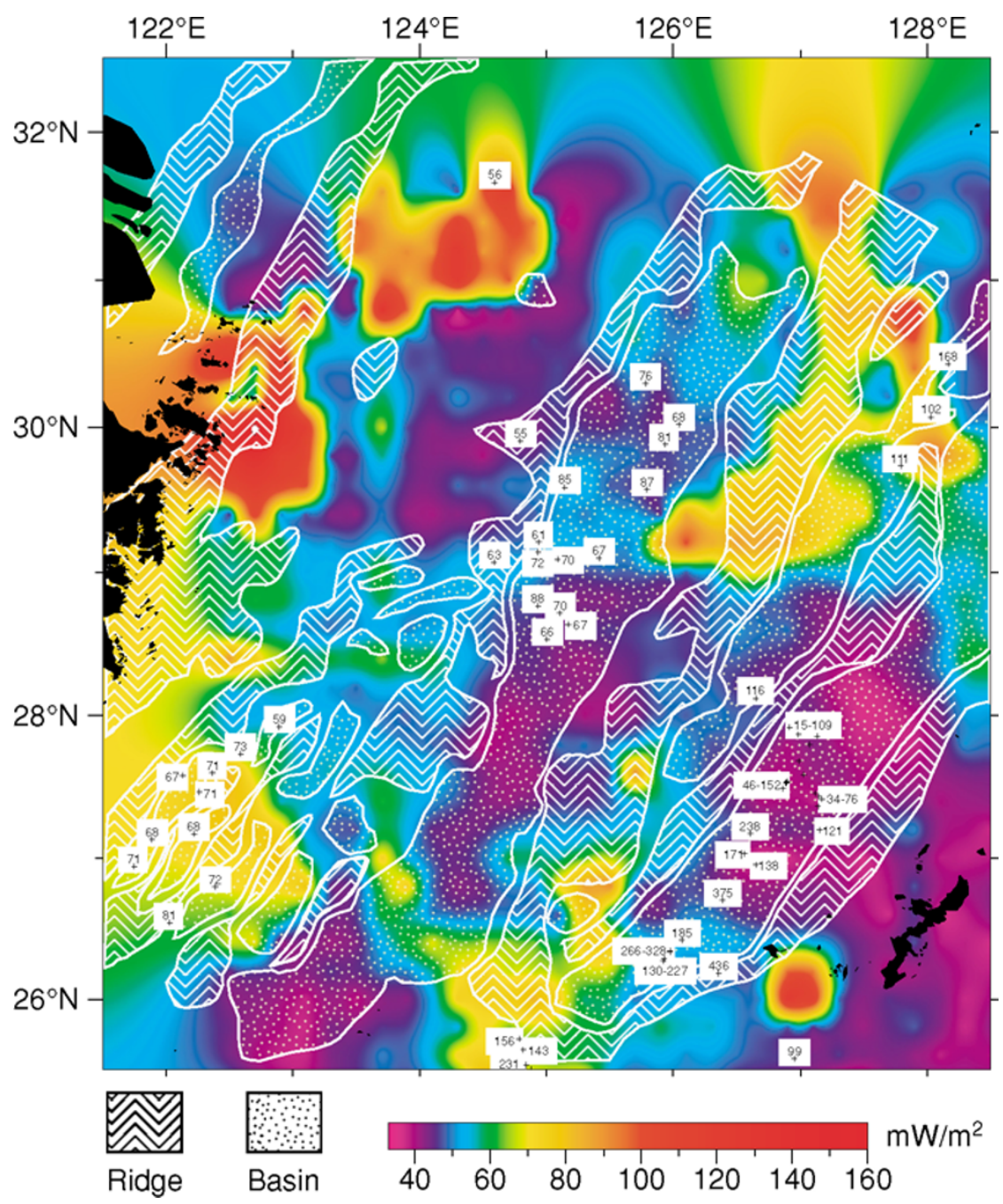

Fig. 6. Heat flow map computed from crust thicknesses $Z b-Z t$ of Fig. 5 (c) with thermal conductivity of $2 \mathrm{~W} / \mathrm{mK}$. Observed heat flow data in $\mathrm{mW} / \mathrm{m}^{2}$ (Herman et al., 1978; Xu et al., 1995; Yamano et al., 1989; Yang et al., 2004; Yoshii, 1979). In white, basins and ridges from Fig. 2(d).

km (Fig. 4(a)) and $Z o$ values obtained with $L=150 \mathrm{~km}$. If we assumed that the crustal thermal conductivity and crustal temperature gradient are constant, the heat flow values and crust thicknesses present a negative correlation:

$$
Q=K\left(T_{\text {Curie }}-T_{\text {surface }}\right) /(Z b-Z t)
$$

where $Q$ is the heat flow $\left(\mathrm{mW} / \mathrm{m}^{2}\right)$,

$K$ the thermal conductivity $(\mathrm{W} / \mathrm{mK})$,

$T_{\text {Curie }}$ and $T_{\text {surface }}$ the temperatures at the base and top of the crust $(K)$.

Figure 6 is the computed heat flow map deduced from the above assumptions with $K=2 \mathrm{~W} / \mathrm{mK}$ deduced from thermal conductivity measurements on cores collected in the Taipei, Tungyintao, Tahchentao and Nanjihtao Basins (Yang et al., 2004), $T_{\text {Curie }}=873^{\circ} \mathrm{K}$ and $T_{\text {surface }}=278^{\circ} \mathrm{K}$. The heat flow values collected in the East China Sea and Okinawa Trough (Herman et al., 1978; Xu et al., 1995; Yamano et al., 1989; Yang et al., 2004; Yoshii, 1979) are plotted on this map. Computed and observed heat flow values are similar in the Tungyintao, Tahchentao and Nanjihtao Basins (70-80 $\mathrm{mW} / \mathrm{m}^{2}$ observed values compared to a mean computed value of $\left.70 \mathrm{~mW} / \mathrm{m}^{2}\right)$ and in the Ho Basin (100 $110 \mathrm{~mW} / \mathrm{m}^{2}$ observed values compared to a mean computed value of $100 \mathrm{~mW} / \mathrm{m}^{2}$ ). However, the measured heat flow values are much higher than computed heat flow values for the Taipei Basin $\left(70-80 \mathrm{~mW} / \mathrm{m}^{2}\right.$ observed values compared to a mean computed value of $45 \mathrm{~mW} / \mathrm{m}^{2}$ ) and for the Okinawa Trough (irregular observed values compared to a mean computed value of $40 \mathrm{~mW} / \mathrm{m}^{2}$ ). If the estimated crustal thickness is thinner than the real one, the calculated heat flow value should be smaller that the observed value. Therefore, for the Taipei Basin, this discrepancy might be partly due to the overestimated thickness of the magnetic crust by the power spectrum method with respect to the true thickness of the crust calculated from basement depth data and the interpretation of gravity data. Several studies suggest that the higher the sedimentation rates are, the lower the heat flow values are (Hutchinson, 1985; Wang and Davis, 1992). As variable sedimentation rates are reported in the western and eastern East China Sea (Huh and Chen, 1999), the variability of heat flow values might be due to changes in sedimentation rates. The Okinawa Trough is an exception because hydrothermal vents have been identified in the central part of the Trough and high heat flow values 
were reported (VAMP area, Sibuet et al., 1987). However, if we do not take into account the high value, the minimum observed values of $45 \mathrm{~mW} / \mathrm{m}^{2}$ might correspond to the calculated heat flow values of about $40 \mathrm{~mW} / \mathrm{m}^{2}$.

\section{Conclusions}

The main conclusions of this study are as follows:

1) Basement depths established by the Shanghai Offshore Petroleum Bureau with all available industry seismic data show the existence of a 30-km-wide, 10-km-deep basin, that we have named the Ho Basin. It extends eastward of the Taiwan-Sinzi Ridge. It is older than the Okinawa Trough and is flanked on its eastern side by a ridge, which corresponds to the Longwan Ridge in the North. This new system of basin and ridge was probably formed during middle Miocene. We recognize now six belts of backarc basins and associated arc volcanic ridges in the East China Sea, which are progressively younger from the Mainland China shoreline (late Cretaceous/early Tertiary) to the Okinawa Trough (middle Miocene to Present). The basement topography of the three more recent belts of basins and ridges is much more developed than the one of the three older belts, possibly in relation with the late Eocene/early Oligocene change in steepness of the Ryukyu slab.

2) We used a power spectrum method to calculate the depth of the top $(Z t)$ and the base $(Z b)$ of the magnetic source by fitting a straight line through the high- and lowwave number portions of the power spectrum, respectively. After optimizing the size of the data squares, we have demonstrated that, except for basins more than $10 \mathrm{~km}$ deep, $Z t$ corresponds to the basement depths and $Z b$, the depth of the Curie point, to the Moho depth. A simple computation of expected heat flow values from the $Z b-Z t$ computed geometry of the magnetic crust and by using a thermal conductivity of $2 \mathrm{~W} / \mathrm{mK}$ shows a good agreement between the observed and computed heat flow values, except in the Taipei Basin and Okinawa Trough where the observed heat flow values are much higher than expected.

Acknowledgments. This work was carried out within the frame of the Sino-French cooperation in Geosciences. We thank the National Science Council (NSC) of Taiwan and the Institut Français in Taipei (IFT) for their financial support during the $\mathrm{Ph}$. D. thesis of one of us (J.-Y. Lin). We particularly acknowledge A. Tanaka and S.-M. Lee for their very pertinent and constructive reviews. We also thank the Shanghai Offshore Petroleum Bureau for kindly providing the depth map of the base of Cenozoic sedimentary rocks in the East China Sea.

\section{References}

Chi, W.-R., Basin characterization, tectonic evolution and hydrocarbon potential of the offshore and onshore Taiwan sedimentary basins, Exploration and Research Reports, 82-114, 1996 (in Chinese with English abstract).

Deschamps, A., K. Okino, and K. Fujioka, Late amagmatic extension along the central and eastern segments of the west Philippine Basin fossil spreading axis, Earth Planet. Sci. Lett., 203, 277-293, 2002.

Garcia-Abdeslem, J. and G. E. Ness, Inversion of the power spectrum from magnetic anomalies, Geophysics, 59, 391-401, 1994.

Geological Suvey of Japan (GSJ) and Coordinating Committee for Coastal and Offshore Geoscience Programmes in East and Southeast Asia (CCOP), Magnetic Anomaly Map of East Asia, Miscellaneous Map Series 32, 1994.

Herman, B. M., R. N. Anderson, and M. Truchan, Extensional tectonics in the Okinawa Trough, geological and geophysical investigations of continental margins, edited by J. S. Watkins, L. Montadert, and P. W. Dickinson, pp. 199-208, Memoir of the American Association of Petroleum Geologists, 1978.

Hilde, T. W. C., C.-S. Lee, and D. E. Vander Zouwen, Tectonic and sedimentation history of Okinawa Trough: implications for development of the East China and Yellow seas, in Korea-U.S. Conference on the Yellow Sea, 1984.

Ho, C. S., An introduction to the geology of Taiwan: Explanatory text of the geologic map of Taiwan, 192 pp., 1984.

Hsu, S.-K., J.-C. Sibuet, S. Monti, C.-T. Shyu, and C.-S. Liu, Transition between the Okinawa trough backarc extension and the Taiwan collision: new insights on the southernmost Ryukyu subduction zone, $M a$ rine Geophys. Res, 18, 163-187, 1996.

Hsu, S.-K., J.-C. Sibuet, and T.-C. Shyu, Magnetic inversion in the East China Sea and Okinawa Trough: tectonic implications, Tectonophysics, 333, 111-122, 2001.

Huang, S.-T., H.-H. Ting, R.-C. Chen, W.-R. Chi, C.-C. Hu, and H.-C. Shen, Basinal framework and tectonic evolution of offshore northern Taiwan, Petroleum Geology of Taiwan, 27, 47-72, 1992.

Huh, C.-A. and H.-Y. Chen, History of lead pollution recorded in East China Sea sediments, Marine Pollution Bulletin, 38(7), 545-549, 1999.

Hutchinson, I., The effects of sedimentation and compaction on oceanic heat flow, J. Geophys. Res., 99, 7161-7175, 1985.

Jin, X., P. Yu, M. Lin, C. Li, and H. Wang, Preliminary study on the characteristics of crustal structure in the Okinawa Trough, Oceanol. Limnol. Sin., 14, 105-116, 1983 (in Chinese with English abstract).

Kong, F., L. A. Lawver, and T.-Y. Lee, Evolution of the southern TaiwanSinzi folded zone and opening of the southern Okinawa Trough, Journal of Asian Earth Sciences, 18, 325-341, 2000.

Lallemand, S., Y. Font, H. Bijwaard, and H. Kao, New insights on 3-D plates interaction near Taiwan from tomography and tectonic implications, Tectonophysics, 335, 229-253, 2001.

Letouzey, J., L. Sage, and C. Müller, Geological and Structural Map of Eastern Asia: Introductory Notes, 52 pp., American Association of Petroleum Geologists Bulletin, Special publication, 1988.

Liu, G.-D., Geologic-Geophysic Features of China Seas and Adjacent Regions, Science Press, Beijing, 424 pp., 1992 (in Chinese).

Menke, W., Geophysical Data Analysis: Discrete Inverse Theory, Academic Press, Orlando, Florida, 269 pp., 1984.

Okubo, Y., R.-J. Graf, R.-O. Hansen, K. Ogawa, and H. Tsu, Curie point depths of the island of Kyushu and surrounding areas, Japan, Geophysics, 50, 481-494, 1985.

Sandwell, D. T. and W. H. F. Smith, New global marine gravity map/grid based on stacked ERS1, Geosat and Topex altimetry, EOS Transactions, American Geophysical Union, 75(16) Spring Meet. Suppl., 321, 1994.

Shuey, R. T., D. K. Schellinger, A. C. Tripp, and L. B. Alley, Curie depth determination from aeromagnetic spectra, Geophys. J. R. Astron. Soc., 50, 75-101, 1977.

Sibuet, J.-C. and S.-K. Hsu, Geodynamics of the Taiwan arc-arc collision, Tectonophysics, 274, 221-251, 1997.

Sibuet, J.-C., J. Letouzey, F. Barbier, J. Charvet, J.-P. Foucher, T. W. C. Hilde, M. Kimura, L.-Y. Chiao, B. Marsset, C. Muller, and J.-F. Stéphan, Backarc extension in the Okinawa Trough, J. Geophys. Res., 92, 1404114063, 1987.

Sibuet, J.-C., S.-K. Hsu, C.-T. Shyu, and C.-S. Liu, Structural and kinematic evolution of the Okinawa trough backarc basin, in Backarc Basins: Tectonics and Magmatism, edited by B. Taylor, pp. 343-378, Plenum Press, New York, 1995.

Sibuet, J.-C., B. Deffontaines, S.-K. Hsu, N. Thareau, J.-P. Le Formal, C.S. Liu, and ACT party, Okinawa Trough backarc basin: Early tectonic and magmatic evolution, J. Geophys. Res., 103, 30,245-30,267, 1998.

Sibuet, J.-C., S.-K. Hsu, and E. Debayle, Geodynamic context of the Taiwan orogen, in Continent-Ocean Interactions Within East Asian Marginal Seas, edited by P. Clift, P. Wang, W. Kuhnt, and D. E. Hayes, pp. 127-158, American Geophysical Union Monograph, Washington, D.C., 2004.

Spector, A. and F. S. Grant, Statistical models for interpreting aeromagnetic data, Geophysics, 35, 293-302, 1970.

Stampolidis, A. and G.-N. Tsokas, Curie point depths of Macedonia and Thrace, N. Greece, Pure and Applied Geophysics, 159, 2659-2671, 2002.

Sun, S. C., The Tertiary basins of off-shore Taiwan, in Proc. 2nd ASCOPE Conf., pp. 125-135, Manila, 1981.

Tanaka, A., Y. Okubo, and O. Matsubayashi, Curie point depth based on 
spectrum analysis of the magnetic anomaly data in East and Southeast Asia, Tectonophysics, 306, 461-470, 1999.

Vander Zouwen, D. E., Structure and Evolution of Southern Okinawa Trough, University of Texas A\&M, College Station, 94 pp., 1985.

Wageman, J. M., T. W. C. Hilde, and K. O. Emery, Structural framework of East China Sea and Yellow Sea, American Association of Petroleum Geologists Bulletin, 54, 1611-1643, 1970.

Wang, K. and E. E. Davis, Thermal effects of marine sedimentation in hydrothermally active area, Geophys. J. Int., 110, 70-78, 1992.

Xu, W. L., R. C. Jiao, J. Y. Yue, and D. W. Wei, Geothermal study on the continent shelf of the East China Sea, Progresses in Geophysics, 10, 32-48, 1995 (in Chinese).
Yamano, M., S. Uyeda, J.-P. Foucher, and J.-C. Sibuet, Heat flow anomaly in the middle Okinawa trough, Tectonophysics, 159, 307-318, 1989.

Yang, S., S. Hu, D. Cai, X. Feng, L. Chen, and L. Gao, Present-day heat flow, thermal history and tectonic subsidence of the East China Sea Basin, Marine and Petroleum Geology, 21, 1095-1105, 2004.

Yoshii, T., Compilation of geophysical data around the Japanese islands (I), Bull. Earthquake Res. Inst., 54, 75-117, 1979 (in Japanese with English abstract).

J.-Y. Lin (e-mail: jylin@ifremer.fr), J.-C. Sibuet (e-mail: jcsibuet@ ifremer.fr), and S.-K. Hsu (e-mail: hsu@oc.gep.ncu.edu.tw) 